\title{
STRUCTURAL ELEMENTS OF THE PLOT AND COMPOSITION OF THE HISTORICAL STORIES OF M. MOROZENKO'S DILOGY "IVAN SIRKO, THE GREAT SORCERER", "IVAN SIRKO, THE GLORIOUS KOSHOVOY"
}

\section{Verba T.}

Post-Graduate Student

ORCID ID 0000-0003-1288-5582

Zaporizhzhya National University

Zaporizhzhya, Zhukovskoho st., 66, 69063, Ukraine

tatyana.verba.71@gmail.com

The writers pay increased attention to the philosophical and historiographical interpretation of events and phenomena, the moral and human essence of historical persons, which absorbs their upbringing, social roles, and innate mental dominants.

The article establishes that the main types of plot creation of historical novels are chronicled, events in which unfold in a temporal sequence, and concentric ("single action"), where events develop in a causal relationship. The conceptual storyline of the novel by M. Morozenko "Ivan Sirko, the Great Sorcerer" is the confrontation of the young main character and the pompous instigator of the youthful detachment Taras Chornoplit. The situation, which is repeated in chivalrous novels, is elegantly modeled. The character of the opponents is checked for stability: the enraged Taras Chornoplit threw Ivan Polovets, who is smaller, on the grass, but the last one did not lose his head and fought back. The fight between them will be one of the plot engines. In the real moments of the greatest tension of the conflict, Sirko's legendary supernatural abilities are woven, because he learned from the characters to see the innermost as well. The confrontation continued.

The struggle between good and evil is organically woven into the outline of the plot of the story "Ivan Sirko, the Glorious Koshovoy": the military fame of the fellow countryman strangled Chornoplit, and he slandered him. Further plot situations are saturated with fantasy: confusing feet, Chornoplit approached the Sich gates, but it was as if someone had moved them. In the morning he woke up far from the gates and was suddenly captured by the Tatars.

The culmination of the clash was Sirko's response to treason against his native land. If Taras carries unworthy fame from here and disgraces his native Merefyanka, then death will be the punishment. The second time Sirko pushed Chornoplit as if he were something nasty and ugly.

According to the results of the study, it was found that episodes of the confrontation between Sirko and Chornoplit constitute an event chain of verification of the moral qualities of the characters. It shows that for the writer, the preservation and development of the best achievements of the past, the proactive search for connections with folklore science fiction is especially relevant and important.

Different orders have compositional components of the novels of dilogy: descriptions, landscapes, portraits, monologues, dialogues, polylogues. They are enriched by the reproduction of the human perception of the world seen and experienced by the characters in stories, the connections between them and events, the fixation of individual communicative situations.

Magical landscapes are consonant with the moods of the citizen of Merefyanka; their souls turn to ancient sources. The majestic landscape of Khortytsia personifies the Cossack defense and glory. Khortytsia represents in the story not only a landscape type, but also a component of historical memory in the process of creating a nation. Emotionally

(C) Верба Т. Ю., 2019 
respectful attitude to the cradle of the Cossacks forms a personal consciousness.

Sirko's verbal and artistic portraits describe a temperamental personality at different age. In postmodern narratives, M. Morozenko, instead of full reproductions of the personality of the main character, draws attention only to the leading features in various life situations.

The novelism of the stories allowed the writer to achieve the desired laconicism in affirming historical memory, human good and justice, the need to talk with the young reader about the most important thing - friendship and child cruelty, truth and injustice, love and hatred, about the attitude to parents and the active character of the little hero, about Cossack feats.

Keywords: opening, culmination, event chain, retrospection.

Formulation of the problem. The formation of national consciousness, the revival processes associated with the consolidation of the nation in particularly difficult circumstances of warfare in the East of Ukraine, require new conceptual and analytical approaches to comprehending historical truth and artistic modeling of historical persons and events. The historical stories about the Cossacks of modern Ukrainian writers deserve special attention and popularization. Single studies do not provide a complete picture of a particular work, and therefore requires a thorough analysis.

Analysis of recent research and publications. Scientific research of S. Andrusiv, I. Dziuba, V. Donchik, M. Zhulinsky, M. Ilnitsky is a theoretical and methodological basis for understanding the problems of the art world, genre, style, transformation of historical truth into art. The artistic specificity of historical stories of K. Ganyukov, N. Gorbach, T. Kara, N. Pavlyuk, G. Polyakova, V. Razzhivin, T. Khomyak has been rethought.

Purpose of the article is to examine the structural elements of the plot and composition of the historical novels of M. Morozenko's dilogy "Ivan Sirko, the Great Sorcerer" and "Ivan Sirko, the Glorious Koshovoy" from the perspective of plotology.

Single studies of M. Morozenko's dilogy do not provide a complete picture of the work, and therefore there is a need for their in-depth analysis; this is a relevance of the study.

The object of the article is: 1) to highlight the achievements of the deep content of the texts; 2) to identify the main elements of the plot, composition; 3) to trace the dynamics of the image of the protagonist in accordance with the structure of the works.

The object of the study is M. Morozenko's dilogy "Ivan Sirko, the Great Sorcerer" and "Ivan Sirko, the Glorious Koshovoy".

The subject of the study is the structural construction of the dylogue.

The novelty of the study: the first analysis of the historical M. Morozenko's dilogy "Ivan Sirko, the Great Sorcerer" and "Ivan Sirko, the Glorious Koshovoy" was carried out in the context of the literary process, traditions and innovations of Ukrainian historical prose, the structure and elements of system-event constructions of works of dilogy were first revealed; the coverage of alternative modeling of historical events and personalities were extended.

Statement of the main material. The plotology of historical prose considers the plot not as a part of the whole, but as a property of the whole. Modeling objective reality in its self-movement, depicting the actions of characters, the plot "checks" the author's position, correlates it with historical truth. Traditionally, the plot is characterized by the importance of content, the depth of aesthetic development and comprehension, the completeness of the deployment of action, the development of characters and circumstances in the art space, which are accompanied by conflicts, oppositions, conflicts of interest, trials" [3, p. 451]. Modern literary criticism operates with the concepts of "external plot" (formation, disclosure of character directly through its participation and self-expression in action) and "internal plot" (development and identification of characters indirectly, through changes in the psyche of the hero) [4, p. 667]. The main types of plot creation of historical 
stories are chronicled, events in which unfold in a temporal sequence, and concentric ("single action"), where events develop in a causal relationship.

Authors' subjectivity of the novelists of the XXI century marked by the desire to create a "self-developing model", the illusion of a special reliability of historical realities and their interpretation, to deprive the textual identification of the author's positions. The conceptual storyline of the novel by M. Morozenko "Ivan Sirko, the Great Sorcerer" is constituted by the tense confrontation between Ivan Sirko and Taras Chornoplit. Its beginning was an offense at the Kupala bonfire: "Only the guy was dispersed to jump through the fire, Taras Chornoplit, the main instigator of a young gang, grabbing the boy by the collar of his shirt, was surprised with a mocking whistle: "Where are you going? ... Way to be a guy! - loud laughter immediately covered the varmint group" [5, p. 39-40].

The first conflict contains an accompanying story: "Ever since his godfather, Mykhailo Dibrov completely disowned him, giving all his free time to little Polovets, Taras Chornoplit slowly warmed the flame of hatred in his soul. He waited a long time for the opportunity to get even with the fellow. Therefore, now, not letting go of the guy from his hands, he rejoiced at his defenselessness" [5, p. 40-41]. The arrogant disposition and temper of Chornoplit revealed in the second case, which occurred on Savior of the Honey Feast Day: "After the temple service ... Taras went to the godfather. In the hands of the little "warrior" a flexible saber gleamed with silver ... So, he, a stubborn guy, can't do it at all, but this young oaf can swing a saber at his head" [5, p. 43]. A check on the stability of behavior in a clash of opponents, seemingly repeated in chivalric novels, was gracefully modeled. "An enraged Taras Chornoplit threw a honeycomb on the grass in his hearts, and then, shaking his fists, rushed at the boy. In response, Ivan sharply carried a saber in the air, and defending himself, went on the offensive" [5, p. 43].

The individualization of the vanity and viciousness of Taras Chornoplit is indicated in the episode on Sich Square, where a group of newcomers showed their skills hardened in bloody "fights" to the Cossacks: "Taras Chornoplit stood behind several Cossacks with their backs to Sirko. For the first time I saw him close, because until now I tried to avoid those meetings. Although, he had heard about Sirko's appearance in Sich, nevertheless circumvented him. And so, they should have seen each other openly" [5, p. 158]. The inevitability of the confrontation is aptly and eloquently illustrated by various reactions to an unexpected act: "- You ?! - the surprised citizen of Mefyanka slowly receded under the force of the handshake of Sirko. In vain he tried to pull out his hand - the enemy held his wrist firmly ... For a minute, two, three - and the hand in which the saber was lowered slowly, hanging limply, like a sagging rod. Then Sirko released the guy's hand... The defeated Cossack, sighing heavily, rubbed his wrists: "Our conversation is not over..." $[5, \mathrm{p}$. 158-159]. "Arcanum of envy" - the title of one of the sections of the novel "Ivan Sirko, the Glorious Koshovoy" figuratively and conceptually interacts with the plot of the work. Another glory strangled Chornoplit, like a lasso. Succumbing to long-standing hatred, he tried to convince the Cossacks: "- Do you think that Sirko defeated me by force two days ago? Not even close! Charms, not otherwise" [5, p. 188]. The Cossacks pushed the slanderer out of the hut. The outline of the story organically intertwined problem of good and evil. Having learned about this incident, Ivan Sirko "called for a conversation of his fellow countryman". "He proudly looked forward, stretching his thin lips in a mocking smile. And when he understood what was at stake, he burst out with fury: "And who are you to teach me ?!" [5, p. 190].

The culmination of the clash was Sirko's response "When you bring unworthy fame from here, you bring our dear Merefyanka to shame, then I'll get even with you! Make seven steps from the Sich gates and a dark grave is your way from here" [5, p. 190-191].

In real moments of the greatest tension of the conflict, Sirko's legendary supernatural abilities are woven: "From the characterists I also learned to see the innermost ... The confrontation continued. Seeing how Sirko gathered for the third time for his allnight "walk", Chornoplit decided ... to prove that he was plotting a big betrayal: "I will subject him to the glare of truth. I will testify to all who is who" [5, p. 192]. The plot 
outline depicts Sirko's mysterious forces and Chornoplit's unprecedented fear: "I saw how Sirko returned the yellow month to the dark sky, I heard him talking to the wolf and hair stood on end on my head" [5, p. 204]. This description is enriched by the legendary dialogue: "- De - De - Devil! - was heard behind Sirko's back. He looked around. Behind him stood Chornoplit, his face bluish and distorted with horror ... The character Sirko, staring intently into the eyes of the frightened Cossack, said with pressure: "This is a dream. You had a dream, that's all". "How is it a dream when I do not sleep ?!" Chornoplit thought, but froze, dispossessed and, having lost his voice, could not object to Sirko" [5, p. 205-206].

Further plot situations are saturated with fantasy: confusing feet, Chornoplit approached the Sich gates, but it was as if someone had moved them. "He goes to them, goes and goes, but he cannot reach them. That fornication attacked, or someone by force holds him and does not allow to get to the Sich" [5, p. 206].

The retrospective reception brought Chornoplit back to the former Kupala bonfire when he persuaded several guys to incinerate the hut in the forest thicket, which people called the witch's nest. And "the old hunchbacked sorceress ... uttered: - When you have a hellish soul, let your whole life turn into hell!" [5, p. 208]. Again, hearing a laugh that he could not confuse with any other, Chornoplit was sure: "The laughter of the foolish sorceress does not portend him a good end to this incomprehensible night" [5, p. 208]. The function of the strong position of the section heading acquired significance: having come in the morning, Chornoplit saw Tatar intelligence and the frightened one rushed to run, but the Tatars managed to throw a tight lasso around the neck of the fail-Cossack. So suddenly Taras was captured. The intrigue, which took place in exceptional conditions, led to an unexpected situation: Sirko "recalling the terrified face of Taras, pleaded guilty to conjuring him into oblivion. Chornoplit did not return to the hut, and Sirko realized that he was in trouble" [5, p. 225]. In subsequent actions of Chornoplit, the writer condemns the greatest sin - betrayal. Having brought the Tatar army to Merefyanka, he "hastily urged fellow countrymen to surrender: "Nobody will touch you, people, I asked everyone ... Please, give the church utensils, the goods hidden in the chests and expose two dozen young prisoners, and the Tatars will leave" [5, p. 234]. After the massacre of the Cossacks detachment with the Tatars, the battle between Chornoplit and Sirko failed - "Shaitan!" Shaitan! - the surviving Tatars shouted and, frightened by Sirko, rushed to wherever. The citizen of Merefyanka, Taras Chornoplit, too, jumping on his horse, rushed off before his nose. Sirko rushed after him. One moment - and he would catch up with the traitor" [5, p. 243].

The plot-semantic unity has a second meeting with Chornoplit, held on Tatar land when the Cossacks released the captives: "Suddenly I felt a wary look on me ... Taras Chornoplit stood before Ivan Sirko - his sworn enemy ... - Traitor! - with fury, Sirko sharply raised his saber ... But he grabbed a young swarthy boy from behind him, lifted him high and said in a trembling voice: - Here, kill him first! This is my son. His mother is a Tatar. From the surprise, Sirko ... suddenly remembering his young sons, lowered his saber" [5, p. 275-276].

So, according to the results of the study, it was found that episodes of the confrontation between Sirko and Chornoplit constitute an event chain of testing the moral qualities of the characters. It shows that for the writer, the preservation and development of the best achievements of the past, the proactive search for connections with folklore science fiction is especially relevant and important. Describing the relationships of the characters, the relationship of the episodes of the depicted events, the ways of depicting and structuring the art world (description, portrait, landscape, monologue, dialogue, polylogue) and viewing angles of subjects of an artwork (author, storyteller, characters) of the composition of M. Morozenko's dilogy about Ivan Sirko have forms of short stories in the novels with the integral role of cross-cutting comparisons and contrasts, tests with the transfer of time and place of events, with the formation of the national identity of the Cossack.

Descriptions, as elements of composition, are enriched by the reproduction of the human perception of the world, the life experience of stories seen and experienced by the 
characters. Merefyanka's description in the novel "Ivan Sirko, the Great Sorcerer" is closely connected with historical events: "Since then, the first Polovtsy, running away from Podillia land from the ominous Polish gentry, stepped on a piece of the Wild Field, irritated, swollen from tears and blood, for decades... Green gardens were strewn between the white houses, because it happened to Ukrainians: the heart is in children, the soul is in song, the life is in cherry orchards" [5, p. 15]. Such a description fulfills a cognitive, expressive, and axiological function: "Generous harvests were drawn to caring hands. And people grew into these lands, were ready to protect them from their worst enemies" [5, $p$. $16]$.

The description of the "black calamity" in Merefyanka became contrasting - Tatars rushed in: "People ran to the church screaming in horror ... Clutching simple weapons they took sickles, forks, spears, axes ... They were ready to stand to their death" [5 , p. 229, 233]. The picture of Merefyanka's defense causes an incredible disgust for the members of the Golden Horde: "It was a terrible struggle. Persistent and unequal. A knot of Merafyanka's citizens defended themselves, courageously restraining the onslaught of the enemy. But what could they do against a sharp weapon and seven times more power? The arrows of the attackers stitched the defenders, who, in order, forever grew into their native land" [5, p. 235].

Landscapes are originally inscribed in the stories of M. Morozenko "Ivan Sirko, the Great Sorcerer" and "Ivan Sirko, the Glorious Koshovoy ". Magical landscapes are consonant with the moods of the citizens of Merefyanka; their souls turn to ancient sources. For example: "On Kupala evening, all people become different. And no wonder ... On a miraculous Kupala night, Kupala himself, summoned from timelessness, blesses the maturity of everything that grows on the earth, and then generously gives all people a love of life" [5, p. 27]. Climbing into the thicket of the forest at night, Ivan "walked between the trees, when suddenly they moved apart, as if they had budged ... After walking a few steps forward, the boy froze in place. Something striking was in this clearing. And not because moonlight was falling from above onto the luxurious silk of grass with changing silver. It somehow enveloped this place in a special way - dividing the forest in a tight silver circle into darkness and light, night and day" [5, p. 49-50]. The "senile voice" brought Ivan to the fern flower.

The majestic landscape of Khortytsia embodies the Cossack defense and glory: "High cliffs, thick meadows, generous grass and reeds - all this has become ... a natural charm of Ukraine. Fortified by a strong shaft, mounted cannons on the towers, Khortytsia was not equal in stability among other secular fortifications" [5, p. 95-96]. Khortytsia represents in the story not only a landscape type, but also a component of historical memory in the national educational process. In the perception of Ivan Sirko, it personifies the Cossack's will. Emotionally respectful attitude to the cradle of the Cossacks forms his personal consciousness and individual ethics. He learns that highly educated men started in the Sich, here they studied literacy and military art, then became Juras - young pupils, squires and assistants of experienced Cossacks.

Sirko's verbal and artistic portraits convey characteristic personality at different times of age. In the postmodern narratives of M. Morozenko, instead of full reproductions, the face of the protagonist draws attention only to the leading features in different life situations. And above all - to the eyes as a mirror of mental state. When the seven-year-old Ivan his mother calls small to participate in the night festival of Kupala, "the splendor of rage, like a reflection of the Kupala bonfire, glowed in his words, reflected warmly in the eyes of a child" [5, p. 32]. To the father's interrogation - "Where did you get this wolf?", to his attempts to find out the truth "Ivan was gloomy silent" [5, p. 72], at the end of the conversation "looked sadly at his father: - I can't tell" [5, p. 74]. Encouraged by the appeal of the godson Myhailo Dubrava, whose Cossack messengers stopped, "the youngster looked with shining eyes - I want to go the Sich [5, p. 84]. On the Sich, with the appearance of this gang - Ivan Dub "the boy's eyes fluttered with joy and satisfaction" [5, p. 97]. Ivan Sirko wiped the "tears in his eyes three times during his lifetime: "The first tears spilled on 
Kupala ..., the second time burst out of his chest with burning heat that day when he was dying in the desert, the third - and the last - when the faithful horse Syvogryviy appeared to him from the next world" [5, p. 362].

The novelism of the tales allowed the writer to achieve the desired laconicism in affirming historical memory, human good and justice, the need to talk with the young reader about the most important thing - friendship and child cruelty, truth and injustice, love and hatred, about the attitude to parents and the active nature of the little hero, about Cossack feats. Almost all 30 novels of the dilogy are based on a certain event, decisive for the moral orientation of the young and already mature age of the hero, which inspires the reader with the feelings of Ivan Polovets - then Ivan Sirko, interests with his unusual fate.

As the plot-compositional forms, real dialogues with people are combined with fantasy ones - with a Magian, a wolf. They primarily express situational sensory arousal of interlocutors. For example, seven-year-old Ivan Polovets on the Kupala holiday, having heard girlish songs, asks his mother about Kupala fun. Emotional percussive tonality is transferred from the questions in the answer in the dialogue on the Khortytsia Sich Square. Questions from Cossack Ivan Dub "But probably someone brought you here?" provoked such a reaction: "- We came ourselves! - the guy exclaimed these words confidently". Further question and answer are indicated by psychological content: "- How did you get here?! - At night I walked through ravines and forests, so that no one would see me. Them slept in the in the densest part of the forest" [5, p. 98].

Intense and intermittent intonations reinforce the dynamism of feelings at the first meeting of Ivan with Sofia "- Girl, wait! She abruptly stopped on the path, flashed her eyes at him: - Who are you to give me orders? - I?! - he admired her tanned forehead, illuminated by green eyes. "Can't you see - a Cossack" [5, p. 132-133]. An extensive dialogue with emphasis on importance and ridicule is transformed in the story of Sofia and Ivan about themselves.

Fantasy dialogues of the seeker of esoteric knowledge Ivan Sirko with a Magian and wolf lead the Cossack along the paths of struggle between Good and Evil, provide the reader with the opportunity to use his own imagination. The first dialogue in the forest more often with the mysterious owner of a creaking voice was a kind of "competition" between two interlocutors: "- I'm not afraid of you! In response, a mocking was heard: "Afraid!" .. Afraid! .. Afraid! .. " [5, p. 50-51]. Nevertheless, this dialogue turned Ivan into the executor of the orders of the Magian and the applicant for the fern, which he attached to the cut little finger. "- Where did the flower go? - Sprouted in your heart. - What for? "Anyone who receives the fern on a Kupala night will have great power" [5, p. 56]. The Magian Roda told Sirko how to find her forest fellow-wolf: “- Don't you know enough to discover the innermost? ... In seven steps, look for the correct answer" [5, p. 195].

Ivan's dialogue with the wolf rests on folklore performances, which went through time and received a special gift that "was fully owned by his distant ancestors - wolves when all the animals on earth could speak": "- Forgive me, friend, I didn't save you - said Sirko. "It's not your fault," said the wolf. "That was to happen ..." [5, p. 202].

Polylogues, polyphony - conversations, "... in which many interlocutors are simultaneously involved" [2, p. 107], define in the narratives of Sirko both solidarity and various sounds of voices, both with indications of characters and without their name. This is clearly illustrated in the description of the election of Ivan Sirko as a Koshovoy on a big council [5, p. 345-346].

Although the compositional components of the novels (exposition, plot, development of action, culmination and denouement) are related by the fate of the main character on the basis of the "necklace" - a combination of historical realities and artistic versions - they have different orders. They fit into the scheme of narrative sequence in the short stories "Life and Death", "Mercy", "Gray Brother", "Khortytsia". Short stories "School of Character", "Born for the Third Time", "Amazing Mystery", "Key to the Solution", "Return Lost" are deprived of a solution, because new tasks and tests related to the construction of their modeling were waiting for Ivan in the nation. The novels "Taras 
Svytka - the Jura Eagle-Eyed" and "Kobzar Taras Verbovyi", although distant in the construction of the novel "Ivan Sirko, the Glorious Koshovoy", are nevertheless united by the pages of the biography of Taras Svytka was blind from a bloody wound and possessed Kobzar art and to whom Sirko gave a Cossack last name Eagle-Eyed. The novels "Escapes of the Cossack family" and "Autumn is the time for weddings" enrich the same compositional type, revealing the history of the Polovtsy clan. In the novel "The Color of Ferns", the development of the action is hindered by two lines - the events of the Kupala holiday and the search for the missing seven-year-old son by mother Maria Polovchikha. In the story "Born Again", the retardation-biography of Dana, the daughter of the Magian Bogorod, is built in.

The denouement of the dilogy is transferred to the "Afterword", which contains eight parts that succinctly describe the death of the Magian - the enemy of Roda, the farewell of the horse Syvogryvyi to Sirko, the midnight meeting of Petro Sirchenko with Syvogryvyi, the death of Sirko's son, Koshovoy 's family, the death of Big Sorcerer, finding letters of will. The ninth part takes the reader to the present: grandfather told his grandson the origin of the name of the Chertomlyk river and the foundation by Ivan Sirko of the new Zaporizhzhya Sich. The continuity of the biography of the famous Koshovoy is motivated by the final author's remark: "Stories about Ivan Sirko are born to this day" [5, p. 366].

Conslusions. According to the results of the study, it was found that episodes of the confrontation between Sirko and Chornoplit constitute an event chain of verification of the moral qualities of the characters. For the writer, the preservation and development of the best achievements of the past, the proactive search for connections with folklore fiction is especially relevant and important. In order to enhance the emotional impact, the writer uses such extra-plot elements: descriptions, landscapes, portraits, science fiction stories, dialogues, polylogues. Expressing the relationships of the characters, the relationship of the episodes of the depicted events, the ways of depicting and structuring the art world and the angles of view of the subjects of an artwork (author, storyteller, characters), compositions of M. Morozenko's dilogy about Ivan Sirko have the form of short stories in the novels with the integral role of through comparisons and contrasts, trials with the transfer of time and place of events, with the formation of the national identity of a Cossack.

\section{СТРУКТУРНІ ЕЛЕМЕНТИ СЮЖЕТУ \\ І КОМПОЗИЦЇ̈ ІСТОРИЧНИХ ПОВІСТЕЙ ДИЛОГЇ̈ М. МОРОЗЕНКО «ІВАН СІРКО, ВЕЛИКИЙ ХАРАКТЕРНИК», «ІВАН СІРКО, СЛАВЕТНИЙ КОШОВИЙ»}

\section{Т. Ю. Верба}

Здобувач кафедри української літератури

ORCID ID 0000-0003-1288-5582

Запорізький національний університет

вул. Жуковського, 66, м. Запоріжжя, 69063, Україна

tatyana.verba.71@gmail.com

Письменники приділяють посилену увагу філософсько-історіографічному осмисленню подій і явищ, морально-людській сутності історичних осіб, яка вбирає $i$ їхнє виховання, і сочіальні ролі, і вроджені ментальні домінанти.

У статті з'ясовано, щзо основними типами сюжетотворення історичних повістей є хронікальний, події в якому розгортаються у часовій послідовності, $i$ концентричний («єдиної дї̈)), де подї розвиваються в причинно-наслідкових зв'язках. Концептуальну сюжетну лінію повісті М. Морозенко «Іван Сірко, великий характерник» складає протистояння юного головного персонажа та пихатого підбурювача молодецької ватаги Тараса Чорноплота. Витончено змодельована ситуація, яка повторюється в лицарських романах $і$ повістях. Перевіряється на стійкість характер протибориів: розлютований Тарас Чорнопліт спересердя кинув 
на траву меншого за себе Івана Половия, але той не розгубився $i$ дав відсіч. Боротьба між ними буде одним із рушїв сюжету. У реальні моменти найбільшого напруження конфлікту вплетено легендарні надприродні здібності Сірка, бо від характерників навчився бачити й потаємне. Протистояння тривало.

Боротьбу добра $i$ зла органічно вплетено в канву сюжету повісті «Іван Сірко, славетний кошовий»: бойова слава земляка душила Чорноплота, $i$ він вдався до наклепів на нього. Подальші сюжетні ситуації насичено фантастикою: плутаючи ногами, Чорнопліт наблизився до січових воріт, але їх мовби хто пересунув. Ранком він прокинувся далеко від воріт і несподівано попав у полон до татар.

Кульмінацією зіткнення стала реакиія-відповідь Сірка щзодо зради рідної землі. Якщо Тарас негідну славу понесе звідсіль $і$ рідну Мерефу зганьбить, то покаранням буде смерть. Вдруге Сірко відтрутив Чорноплота, штовхнув так, ніби то було щось бридке та потворне.

За результатами дослідження встановлено, щзо епізоди протистояння Сірка $i$ Чорноплота становлять подієвий ланцююг перевірки моральних якостей персонажів. Він показує, щзо для письменниці особливо актуальним і важливим є збереження й розвиток кращихх здобутків минулого, ініціативні пошуки зв'язків із фольклорною фантастикою.

Різні порядки мають композиційні складники новел дилогії: описи, пейзажі, портрети, монологи, діалоги, полілоги. Збагачено їх відтвореннями людського сприйняття світу, побаченого та пережитого персонажами повістей, зв'язків між ними та подіями, фіксуванням окремих комунікативних ситуацій.

Магічні пейзажі суголосні настроям мереф'ян, навертають їхні душі до тисячолітніх прадавніх джерел. Величний пейзаж Хортиці уособлює козаиьку оборону $і$ славу. Хортиця презентує в повісті не лише ландшафтний тип, а й компонент історичної пам'яті в націєтворчому процесі. Емочійно-ианобливе ставлення до колиски козаитва формує особисту свідомість.

Словесно-мистецькі портрети Сірка передають характерницьку індивідуальність у різні пори віку. У постмодерних повістях М. Морозенко, замість повних відтворень обличчя головного героя, звертає увагу лише на провідні риси в різних життєвих ситуаціях.

Новелістичність повістей дала змогу письменнииі досягти бажаного лаконізму в утвердженні історичної пам'яті, людських добра i справедливості, необхідності говорити з юним читачем про найважливіше - дружбу та дитячу жорстокість, правду $i$ кривду, любов $і$ ненависть, про ставлення до батьків $i$ активну натуру малого героя, про козацькі подвиги.

Ключові слова: зав'язка, кульмінація, подієвий ланцююг, ретроспекиія

\section{REFERENCES}

1. Kachura O. "He was born for more" : the image of Ivan Sirko in M. Morozenko's story "Ivan Sirko, the Great Sorcerer". Cossacks in the cultural space of Ukraine and the world. - Zaporizhzhya , 2015. Ukraine.

2. Encyclopedia of Literary Studies: in 2 volumes/ author Kovaliv Yu. Kyiv: Publishing center "Akademia", 2007. V. 1, 608 p.

3. Encyclopedia of Literary Studies: in 2 volumes/ author Kovaliv Yu. Kyiv: Publishing center "Akademia", 2007. V. 2, 624 p.

4. Vocabulary-dictionary of Literary Studies/ authors Gromiak R., Kovaliv Yu., Teremko V. Kyiv : Publishing center "Akademia", 2007. 752 p.

5. Morozenko M. Ivan Sirko, the Great Sorcerer. Ivan Sirko, the Glorious Koshovoy. Lviv: Publishing House of Staryi Lev, 2015. 366 p.

6. Pavlenko I. Mythologization of historical figures in folklore prose of Zaporizhzhya region. Bulletin of Zaporizhzhya State University. Series: Philology. Zaporizhzhya : ZNU, 2001. No. 1. P. 78-83. 
7. Pankrashkina Zh. M. Morozenko's dilogy of about Ivan Sirko at an extra-curricular reading lesson in the 6-th grade. Cossacks in the cultural space of Ukraine and the world. Zaporizhzhya : ZNU, 2015. P. 106-107.

8. Romanenko L. The personality of Ivan Sirko in Ukrainian literature (based on the works of M. Morozenko "Ivan Sirko, the Great Sorcerer", "Ivan Sirko, the Glorious Koshovoy ") Bulletin of Mariupol State University. Series: Philology. Mariupol: MDU, 2013. Issue 9. P. 56-62.

9. Khomiak T., Ivaschenko O. Artistic modeling of the image of Ivan Sirko in M. Morozenko's dilogy "Ivan Sirko, the Great Sorcerer", "Ivan Sirko, the Glorious Koshovoy ". Bulletin of Zaporizhzhya National University. Series: Philology. Zaporizhzhya : ZNU, 2016. No. 2. P. 245-253.

\section{СПИСОК ВИКОРИСТАНИХ ДЖЕРЕЛ}

1. Качура О. «Він був народжений задля більшого»: образ Івана Сірка в повісті М. Морозенко «Іван Сірко, великий характерник». Козацтво в культурному просторі Украӥни і світу. Запоріжжя : ЗНУ, 2015. С. 70-72.

2. Літературознавча енциклопедія : у 2-х т. / авт-уклад. Ю. Ковалів. Київ : ВЦ «Академія», 2007. Т. 1.608 с.

3. Літературознавча енциклопедія : у 2-х т. / авт-уклад. Ю. Ковалів. Київ : ВЦ «Академія», 2007. Т. 2. 624 с.

4. Літературознавчий словник-довідник / уклад. Р. Гром’як, Ю. Ковалів, В. Теремко. Київ : ВЦ «Академія», 2007. 752 с.

5. Морозенко М. Іван Сірко, великий характерник. Іван Сірко, славетний кошовий. Львів : Вид-во Старого Лева, 2015. 366 с.

6. Павленко I. Міфологізація історичних постатей у фольклорній прозі Запорізького регіону. Вісник Запорізького державного університету. Серія: Філологічні науки. Запоріжжя : ЗНУ, 2001. № 1. С. 78-83

7. Панкрашкіна Ж. Дилогія М. Морозенко про Івана Сірка на уроці позакласного читання у 6 класі. Козацтво в культурному просторі України і світу. Запоріжжя : 3НУ, 2015. С. 106-107.

8. Романенко Л. Постать Івана Сірка в українській літературі (на матеріалі творів М. Морозенко «Іван Сірко, великий характерник», «Іван Сірко, славетний кошовий») Вісник Маріупольського держсавного університету. Серія : Філологія. Маріуполь : МДУ, 2013. Випуск 9. С. 56-62.

9. Хом'як Т., Іващенко О. Художнє моделювання образу Івана Сірка в дилогії М. Морозенко «Іван Сірко, великий характерник», «Іван Сірко, славетний кошовий». Вісник Запорізького національного університету. Серія : Філологічні науки. Запоріжжя: ЗНУ, 2016. № 2. С. 245-253.

Received: 28 September, 2019

(C) Верба Т. Ю., 2019 
